\title{
INFLUENCE OF ORGANIC FERTILIZATION AND IRRIGATION ON QUALITY OF MARAQI CULTIVAR VIRGIN OLIVE OIL
}

\author{
ELSORADY, M. ELSAYED I. ${ }^{1}$, A. S. MOHAMED ${ }^{2,3}$ \\ AND ENAAM SH.A.MOHAMED ${ }^{1}$
}

1. Oils and Fats Dept, Food Tech. Res. Inst., ARC., Giza, Egypt.

2. Horticulture Research Institute, ARC., Giza, Egypt.

3. Arid Land Agriculture Dept, Fac. of Meteorology, Environment and Arid Land Agriculture, King Abdulaziz University, Jeddah, Saudi Arabia.

(Manuscript received 2 March 2014)

\begin{abstract}
This study was carried out through season (2010-2011) on Maraqi cv. trees, 7 years old, in organic farm at Barqash, Giza governorate, Egypt. The investigation aimed to study Influence of organic fertilization and irrigation on quality of Maraqi cultivar virgin olive oil. The following treatments were applied: T1 : (100\% Poultry manure $+75 \%$ irrigation), T2(75\% Poultry manure+ $75 \%$ irrigation), T3(100\% compost $+75 \%$ irrigation), $\mathrm{T} 4(75 \%$ compost $++75 \%$ irrigation), $\mathrm{T} 5$ (humic acid $+75 \%$ irrigation), T6 (Farm yard manure (FYM) + 75\% irrigation), T7 ( $100 \%$ Poultry manure $+100 \%$ irrigation), T8 (75\% Poultry manure + $100 \%$ irrigation), T9 (100\% compost $+100 \%$ irrigation), T10 (75\% compost $+100 \%$ irrigation), T11 (humic acid $+100 \%$ irrigation) and T12 (Farm yard manure (FYM) $+100 \%$ irrigation). Results of this study indicated that all organic c.v Maraqi VOOs were classified as extra virgin olive oil. VOOs obtained from Farm yard manure and compost had the highest phenols and oxidative stability. $\mathrm{N}$ content in used organic fertilizers had reverse (negative) relationship on content of phenols. On the contrary, Organic matter had positive relationship on content of phenols. VOOs obtained from $75 \%$ irrigation had higher total phenol content and higher oxidative stability than that treatment with $100 \%$ irrigation. In the case of (Organic fertilization $+75 \%$ irrigation), monounsaturated fatty acids increased as the fertilizer dose increased. On the contrary, the content of polyunsaturated fatty acids decreased with it. In particular, the oleic acid content increased, and linoleic fatty acid content decreased with fertilizer dose increased. The monounsaturated/polyunsaturated fatty acid ratio increased as the fertilizer dose increased.
\end{abstract}

KEY-WORDS: cv. Maraqi - Irrigation - Organic fertilization - quality Virgin Olive oil

\section{INTRODUCTION}

Organic farming is a new system for agriculture production to avoid the use of chemical and synthetic fertilizers. Environmental effects on human health promoted growers to convert to organic production (AL-Kahtani and Ahmed, 2012). 
Organic matter is not only necessary for plant nutrition as slow release fertilizers but also essential for efficient plant production system (AL-Kahtani and Ahmed, 2012).

Compost was more efficient in improving soil physical and chemical characteristics and enhancing growth of olive trees. Sheep and chicken manures were more efficient in improving soil physical and chemical characteristics and enhancing growth of olive trees. Therefore, these media are recommended for olive cultivation under the arid and semi-arid regions, which are limited in water resources, especially sandy soil (AL-Kahtani and Ahmed, 2012).

Farmyard manure is a heterogeneous composted organic material consisting of dung, crop residue, and or household sweeping in various stages of decomposition. Farmyard manure is mostly available and produced in farms, and is an important organic resource for agricultural production in live stock based farming systems in many countries including semi-arid regions of India (Motavalli et al., 1994)

Organic fertilization maintains adequate mineral content in leaves during growth cycles of the olive trees for having economical yield, also increases fruit set percentage, reduces fruit dropping weaves and improves oil properties. Organic virgin olive oil was superior qualities compared to the conventional virgin olive oil i.e. lower acidity value, lower peroxide index, higher stability and higher organoleptic scoring (Gutierrez et al., 1999, AL-Kahtani and Ahmed, 2012)

Olives (Olea europaea) are produced for extraction of olive oil for human consumption and for processing as table olives. Many factors may affect olive quality, including cultural practices such as fertilization (Fernandez-Escobar et al., 2006).

Olive oil is a basic constituent of the Mediterranean diet. Consumption has significantly increased in the last years as a result of its nutritional value and recognized benefits for human health. Factors such as cultivar, weather and soil conditions, fruit ripeness, agronomic practices, and oil extraction process modify oil chemical composition and organoleptic characteristics. Within the agronomic practices, particular attention is being paid to irrigation and, more recently, fertilization (MoralesSillero et al., 2007).

Virgin olive oil is obtained directly from the olive by applying physical methods, and presents some nutritional and sensorial characteristics that distinguish it from other edible oils, which have to be refined for consumption. Because of its high oleic acid content, olive oil is considered as monounsaturated oil, showing a medium linoleic acid percent (Fernandez-Escobar et al., 2006).

Virgin olive oil contains a group of minor compounds with a high antioxidant activity. Among these compounds can be highlighted the phenolic compounds, which 
have nutritional effects, protect the oils against oxidation and are related with some sensorial characteristics. A high correlation has been described between the phenolic content and the oil oxidative stability. Moreover, these compounds are responsible for the bitterness and the pungency of oils (Fernandez-Escobar et al., 2006).

Vitamin $\mathrm{E}$ is another important antioxidant that in virgin olive oils is formed by $a^{-}, \beta$ - and $\gamma$ - tocopherol. Usually, vitamin $E$ activity of virgin olive oils is higher than those described for other edible oils. Pigments are responsible for oil color that is considered as a quality parameter. In virgin olive oil can be found carotenoids and chlorophyllic pigments. Carotenoids have antioxidant activity protecting oil from autoxidation, whereas chlorophyll acts as prooxidant in light (Fernandez-Escobar et al., 2006).

Composition of virgin olive oil is affected by several agronomical factors such as cultivar, fruit ripeness, agroclimatic conditions, and some growing techniques. Fertilization and pruning seem to have no effect on regulated oil quality parameters such as acidity, peroxide value and UV-vis absorpation (Fernandez-Escobar et al., 2006).

Gutierrez et al.(1999) reported the type of cultivation have an influence on the quality parameters of the oil. In particular, oils from organic cultivation showed lower acidity and peroxide value and higher stability to oxidation (Rancimat) and sensorial analysis scoring when compared to conventional systems.

Many authors observed that irrigation did not affect fatty acid composition of olive oil . However, lower values of the monounsaturated/polyunsaturated ratio and of the unsaturated/saturated ratio were found in oil from irrigated olive trees than that from non irrigated trees (Morales-Sillero et al., 2007).

Additional water supplies have positive effects on fruit yield. Oil content does not always increase with irrigation, although oil quality is usually modified. In particular, polyphenol content, $\mathrm{K}_{225}$ (bitterness), and oxidative stability have been observed to decrease with the increase in applied water. The olive oil antioxidant activity is principally the result of the high polyphenol content, particularly orthodiphenols. Phenolic compounds are part of the polar fraction of virgin olive oils and they are related to the pungent astringency and bitter taste. Like other food products, these compounds have interest as a result of their potential for human health. A high correlation between polyphenol content and $K_{225}$ extinction coefficient has been shown. The oxidative stability parameter allows us to estimate the oil susceptibility to oxidative degeneration and is positively correlated with polyphenol content, tocopherol content, fatty acid composition, carotenoid, and chlorophyll 
pigments. The polyphenol content-stability correlation is greater in oils from green than from black fruits (Morales-Sillero et al., 2007).

The widely accepted assumption that fertilization practices have little if any effect on oil quality is not supported by results from recent studies. Thus, FernandezEscobar et al.(2006) found that nitrogen over fertilization in 'Picual' olive trees induced a decrease in polyphenol content and, in consequence, both in $\mathrm{K}_{225}$ and oxidative stability of virgin olive oil. A significant decrease in saturated fatty acids content, and so an increase in unsaturated/saturated and polyunsaturated/ saturated acid ratios, was observed when high levels of $\mathrm{N}$ and $\mathrm{K}$ were supplied to the soil around the tree trunks in a 'Carrasquen ${ }^{a}$ ' olive orchard. On the contrary, no differences in oil content and quality were found when $\mathrm{N}$ and $\mathrm{K}$ foliar applications were made on 'Carolea' olive trees (Morales-Sillero et al., 2007).

It has been observed that an excess of fertilizer applied by fertigation decreased fruit quality in other fruit tree species. In particular, high $\mathrm{N}$ doses caused thicker peels in orange as well as later development of color in orange, grapefruit, and apple. In olive, despite the general practice of this method in intensive orchards, little is known about the effect on oil quality. No significant differences in oil chemical composition were found in young 'Empeltre' olive trees after 3 years of different nitrogen treatments (Morales-Sillero et al., 2007).

Agronomic practices, in particular fertilization and irrigation, modify table olive quality. It is known that an excess of nitrogen fertilization can negatively affect olive production and delay fruit ripeness. A deficit of nitrogen, however, may lead to a decrease in fruit number, size, and color, as well as early fruit ripeness. Concerning irrigation, this practice increases fruit fresh weight, volume, pulp/stone ratio, and mesocarp water content, but may also negatively affect fruit quality by decreasing the firmness and sugar concentration. On the other hand, it seems that polyphenol concentration, bitterness, flavor, color, and aromatic potential characteristics decrease during fruit ripening with water availability (Morales-Sillero et al., 2008).

Morales-Sillero et al.(2007) studied the effect of fertigation with increasing doses of a $4 \mathrm{~N}-1 \mathrm{P}-3 \mathrm{~K}$ fertilizer on the oil quality and oil yield. Although oil yield increased with the fertilizer dose, due to an increase on the number of fruits, the oil quality was negatively affected in trees fertilized with 400 and $600 \mathrm{~g}$ of nitrogen per tree and irrigation season compared with control trees and trees with $200 \mathrm{~g}$ of nitrogen.

The aim of this study was to evaluate the influence of organic fertilization and irrigation on quality of Maraqi cultivar virgin olive oil 


\section{MATERIALS AND METHODS}

\subsection{Experimental details.}

This study was carried out through season (2010-2011) on Maraqi cv. trees, 7 years old, in organic farm at Barqash, Giza governorate, Egypt.The investigation aimed to study the effect of applying different organic fertilizers and different irrigation treatments on olive oil quality. The following treatments in table (1) were applied:

Table 1. Treatments were applied in the study.

\begin{tabular}{|l|l|}
\hline Code & Treatments \\
\hline T1* & $100 \%$ Poultry manure \\
\hline T2* & $75 \%$ Poultry manure \\
\hline T3* & $100 \%$ Compost \\
\hline T4* & $75 \%$ Compost \\
\hline T5* & Humic Acid \\
\hline T6* & Farm Yard Manure (FYM) (control) \\
\hline T7** & $100 \%$ Poultry manure \\
\hline T8** & $75 \%$ Poultry manure \\
\hline T9** & $100 \%$ Compost \\
\hline T10** & $75 \%$ Compost \\
\hline T11** & Humic Acid \\
\hline T12** & Farm Yard Manure (FYM) (control) \\
\hline
\end{tabular}

$*=$ with $75 \%$ of water irrigation required $\left(1800 \mathrm{~m}^{3} /\right.$ faddan $/$ year $), * *=$ with $100 \%$ of water irrigation required $\left(2400 \mathrm{~m}^{3} /\right.$ faddan/year).

All treatments supplemented with Natural Rock and microbial fertilizers, as source of other mineral salts such as $\mathrm{P}, \mathrm{K}, \mathrm{S}, \mathrm{Ca}, \ldots$

Tables 2 and 3 show some physical and chemical characteristic of used organic fertilizers, the quantity of each dose was estimated on basis of $1000 \mathrm{~g} \mathrm{~N} /$ tree.

Table 2 . Nitrogen content and quantity of different used organic fertilizers.

\begin{tabular}{|c|c|c|c|c|c|c|}
\hline \multirow{2}{*}{$\begin{array}{l}\text { Nitrogen } \\
\text { content \% }\end{array}$} & \multicolumn{2}{|c|}{ POULTRY manure } & \multicolumn{2}{|c|}{ COMPOST } & \multirow{2}{*}{ HUMIC Acid } & \multirow{2}{*}{$\begin{array}{c}\text { Farm yard } \\
\text { manure (FYM) }\end{array}$} \\
\hline & $100 \%$ & $75 \%$ & $100 \%$ & $75 \%$ & & \\
\hline $\mathrm{N} \%$ & \multicolumn{2}{|c|}{2.70} & \multicolumn{2}{|c|}{1.32} & 2.07 & 2.42 \\
\hline $\begin{array}{l}\text { Quantity } \\
\text { (Kg) }\end{array}$ & 37 & 27.75 & 71 & 53.25 & $\begin{array}{c}100 \mathrm{ml} \text { of Humic } \\
\text { acid in } 20 \mathrm{~L} \text { water, } \\
\text { monthly direct to } \\
\text { tree. }\end{array}$ & 41 \\
\hline
\end{tabular}


Table 3. Comparison between characteristics of Compost and Farm yard manure (FYM).

\begin{tabular}{|c|c|c|}
\hline Characteristics & Compost & Farm yard manure (FYM) \\
\hline Density $\left(\mathrm{m}^{3} / \mathrm{kg}\right)$ & 543 & 580 \\
\hline $\mathrm{pH}$ & 8.30 & 8.36 \\
\hline Total N \% & 1.32 & 2.42 \\
\hline $\mathrm{P} \%$ & 0.77 & 0.82 \\
\hline $\mathrm{K} \%$ & 0.86 & 1.24 \\
\hline Organic matter \% & 31.05 & 46.65 \\
\hline
\end{tabular}

\subsection{Some Properties of Olives}

\subsubsection{Physical characteristics of fruit and yield}

Different healthy fruit samples were randomly collected to measure some variables related to physical characteristics: fresh fruit weight $(\mathrm{g})$, Fruit length $(\mathrm{cm})$, Fruit width $(\mathrm{cm})$, Stone weight $(\mathrm{g})$, Stone length $(\mathrm{cm})$, Stone width $(\mathrm{cm})$ and the yield per tree.

\subsection{Some Properties of Organic Olive Oils}

\subsubsection{Oil samples}

After harvest olive, the oil was immediately extracted by means of the continuous extraction system two-phases. The samples were then kept in dark glasses at $-18{ }^{\circ} \mathrm{C}$, until analysis.

\subsubsection{Quality parameters of virgin olive oil}

Quality parameters of virgin olive oil were determined according to methods established by the European Commission regulation (EEC) No. 2568/91 (EEC, 1991): free acidity, peroxide value and specific UV absorption characteristics $\left(K_{232}, K_{270}, \Delta K\right)$. Free acidity (FA) refers to the free acidity content of the oil and is expressed as the percentage of oleic acid (\%), the peroxide value (PV), which indicates the amount of hydroperoxides produced in primary oxidation processes, is reported as mill equivalents of active oxygen per kilogram of oil (meq. $\mathrm{O}_{2} / \mathrm{kg}$ ), the extinction coefficients $K_{232}$ and $K_{270}$ are calculated from the absorptions at 232 and $270 \mathrm{~nm}$, respectively and $\Delta K$ are widely related to the preservation state of the oil. All the parameters were determined in triplicate and the average values for each sample were calculated.

\subsubsection{Total phenols:}

Olive oil samples were extracted three times with $10 \mathrm{ml}$ of a methanol/water mixture (60: $40 \mathrm{~V} / \mathrm{V})$. The pooled extracts were washed with $10 \mathrm{ml}$ of $\mathrm{n}$-hexane and solvents were removed with a rotary evaporator (Buchi, Switzerland). Total phenols (TP) content of the methanolic extract of olive oil were calorimetrically determined using the Folin-Ciocalteu method (Gamez-Meza et al., 1999). 


\subsubsection{Oxidative stability}

Oxidative stability was evaluated by the Rancimat method (Gutierrez, 1989). Stability was expressed as the oxidation induction time (hours), measured with the Rancimat 679 apparatus (Metrohm Co., Switzerland), using an oil sample of $5 \mathrm{~g}$ heated to $100^{\circ} \mathrm{C}$ with air flow of $20 \mathrm{~L} / \mathrm{h}$.

\subsubsection{Determination of Chlorophyll and carotenoid}

Chlorophyll and carotenoid were determined at 644, 663 and $440 \mathrm{~nm}$ in acetone using specific extinction values, by the method described by Wensttein (1957).

\subsubsection{Gas chomatography analysis}

\section{- Methylation of fatty acids}

An aliquot of fatty acids after saponification and acidification of olive oil, about $10 \mathrm{mg}$, was dissolved in $2 \mathrm{ml}$ hexane and then $0.4 \mathrm{ml}$ of $2 \mathrm{~N} \mathrm{KOH}$ in anhydrous methanol was added (Cossignani et al., 2005), after $3 \mathrm{~min}, 3 \mathrm{ml}$ water was added. The organic layer, separated by centrifugation, was dried over anhydrous sodium sulfate, and then concentrated, with a $\mathrm{N}_{2}$ stream to around $0.5 \mathrm{ml}$ for GC analysis of fatty acids methyl esters (FAME) as described below.

\section{- GC analysis of FAME}

Agilent 6890 series GC apparatus provided with a DB-23 column $(60 \mathrm{~m} \times 0.32$ $\mathrm{mm} \times 0.25 \mu \mathrm{m}$ ) was used. Oven temperatures were $150^{\circ} \mathrm{C}$ ramped to $195^{\circ} \mathrm{C}$ at $5^{\circ} \mathrm{C}$ $\min ^{-1}$, ramped to $220^{\circ} \mathrm{C}$ at $10^{\circ} \mathrm{C} \mathrm{min}^{-1}$ and flow rate was $1.5 \mathrm{~min}^{-1}$. Fatty acids results after the previous procedures steps were transformed into methyl esters and directly injected into the GC.

\subsubsection{Sensory analysis}

Sensory analysis of the samples was carried out by trained panellists according to the method described in International Olive Council (COI/T.20/Doc. No 15/Rev. 6, November 2013 (IOC, 2013a).

\subsubsection{Overall Quality Index (OQI)}

The overall quality index (OQI) was introduced by the International Olive Oil Council (IOC) in 1990 to express virgin olive oil quality numerically (IOC, 1990). This is a scale from 0 to 10 that considers four quality parameters: the score for sensory evaluation (SE), free acidity (FA), $\mathrm{K}_{270}$, and peroxide value (PV), according to the following equation:

$$
\mathrm{OQI}=2.55+0.91 \mathrm{SE}-0.78 \mathrm{FA}-7.35 \mathrm{~K} 270-0.066 \mathrm{PV} \text {. }
$$




\section{RESULTS AND DISCUSSION}

\subsection{Physical characteristics of fruit and yield}

Table (4) shows physical characteristics and yield of fruits for organic olive trees. Data showed that T2 (75\% Poultry $+75 \%$ water irrigation required) had the highest fruit weight $8.63 \mathrm{~g}$, followed by T3 (100\% compost+ 75\% water irrigation required), $8.25 \mathrm{~g}$. On the contrary, T6 (FYM+ 75\% water irrigation required) and T10 (75\% compost+ $100 \%$ water irrigation required) had the lowest fruit weights 5.05 and $6.21 \mathrm{~g}$, respectively.

Table 4. Physical characteristics and yield of fruits of organic olive trees.

\begin{tabular}{|c|c|c|c|c|c|c|c|c|c|}
\hline \multirow{2}{*}{\multicolumn{2}{|c|}{ Treat. }} & \multicolumn{6}{|c|}{ Fruits and stones measurements } & \multirow[b]{2}{*}{$\begin{array}{c}\text { yield } \\
\text { /tree } \\
(\mathrm{Kg})\end{array}$} & \multirow[b]{2}{*}{$\begin{array}{l}\text { Yields } \\
\text { mean }\end{array}$} \\
\hline & & $\begin{array}{l}\text { Fresh } \\
\text { fruit } \\
\text { weight }\end{array}$ & $\begin{array}{l}\text { Fruit } \\
\text { length } \\
(\mathrm{cm})\end{array}$ & $\begin{array}{l}\text { Fruit } \\
\text { width } \\
(\mathrm{cm})\end{array}$ & $\begin{array}{l}\text { Stone } \\
\text { weight } \\
\text { (a) }\end{array}$ & $\begin{array}{c}\text { Stone } \\
\text { length } \\
(\mathrm{cm})\end{array}$ & $\begin{array}{l}\text { Stone } \\
\text { width } \\
(\mathrm{cm})\end{array}$ & & \\
\hline \multirow{6}{*}{ 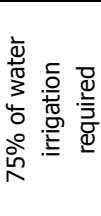 } & T1 & 7.45 & 2.72 & 2.22 & 1.1 & 1.79 & 0.98 & 58.33 & \multirow{6}{*}{41.885} \\
\hline & T2 & 8.63 & 2.83 & 2.35 & 1.18 & 1.77 & 1.08 & 56.66 & \\
\hline & T3 & 8.25 & 2.76 & 2.27 & 1.2 & 1.75 & 1 & 36.66 & \\
\hline & T4 & 6.58 & 2.63 & 2.09 & 1.06 & 1.71 & 0.99 & 33.33 & \\
\hline & T5 & 6.45 & 2.60 & 2.11 & 1.08 & 1.7 & 1.02 & 36.33 & \\
\hline & T6 & 5.05 & 2.43 & 1.88 & 0.96 & 1.64 & 0.96 & 30 & \\
\hline \multirow{6}{*}{ 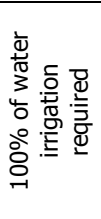 } & T7 & 7.46 & 2.77 & 2.22 & 1.11 & 1.77 & 0.98 & 53.33 & \multirow{6}{*}{41.108} \\
\hline & T8 & 6.8 & 2.67 & 2.47 & 1.18 & 1.76 & 1.02 & 30 & \\
\hline & T9 & 6.26 & 2.58 & 2.05 & 1.08 & 1.69 & 0.92 & 40 & \\
\hline & T10 & 6.21 & 2.56 & 2.05 & 1.11 & 1.75 & 0.98 & 46.66 & \\
\hline & $\mathrm{T} 11$ & 7.7 & 2.76 & 2.25 & 1.15 & 1.75 & 1 & 36.66 & \\
\hline & T12 & 7.63 & 2.71 & 2.23 & 1.13 & 1.76 & 0.97 & 40 & \\
\hline
\end{tabular}

Results in table (4) revealed that T1 (100\% poultry+ $75 \%$ water irrigation required) and T2 (75\% poultry+ $75 \%$ water irrigation required) had the highest yield per tree 58.33 and $56.66 \mathrm{~kg}$, respectively. On the other hand, T6 (FYM+ 75\% water irrigation required) and T8 (75\% poultry $+100 \%$ water irrigation required) had the lowest yield per tree $30 \mathrm{~kg}$ for each treatment.

Effect of irrigation on yield of fruits per tree (Table:4) showed that treatment with $75 \%$ water irrigation required had higher yield, $41.885 \mathrm{~kg}$, than treatment with $100 \%$ water irrigation required, $41.108 \mathrm{~kg}$.

\subsection{Quality parameters of virgin olive oil}

Table (5) shows effect of organic fertilization and irrigation on quality parameters of Maraqi virgin olive oil. In all organic virgin olive oils, acidity values were ranged from 0.13 to $0.31 \%$ as Oleic acid, the lowest FFA was $0.13 \%$ for T4 and T12. The highest FFA was $0.31 \%$ forT9. The upper limit of $0.8 \%$ for acidity values of "Extra" oils was not surpassed in all studied oils. In terms of the peroxide value, all studied organic oils were ranged from 4.08 to 7.07 (meq O $2 / \mathrm{kg}$ oil). The limit set for "Extra" oils is 20 meq $\mathrm{O}_{2} / \mathrm{kg}$ oil. The specific extinction coefficient $\mathrm{K}_{232}, \mathrm{~K}_{270}$ and $\Delta \mathrm{k}$ for all organic oils complied with the limits for "Extra" oils for $K_{232}$ of $\leq 2.50, K_{270}$ of $\leq$ 0.22 and $\leq 0.01$ for $\Delta k$ were not reached (IOC, 2013b). 
Table 5. Effect of organic fertilization and irrigation on quality parameters of cv. Maraqi virgin olive oil.

\begin{tabular}{|c|c|c|c|c|c|c|c|c|c|c|c|c|}
\hline \multirow{3}{*}{ Characteristics } & \multicolumn{12}{|c|}{ Treatments } \\
\hline & \multicolumn{6}{|c|}{ Organic fertilization $+75 \%$ irrigation } & \multicolumn{6}{|c|}{ Organic fertilization $+100 \%$ irrigation } \\
\hline & $\mathrm{T} 1$ & $\mathrm{~T} 2$ & T3 & T4 & T5 & T6 & $\mathrm{T7}$ & T8 & T9 & $\mathrm{T} 10$ & $\mathrm{~T} 11$ & $\mathrm{~T} 12$ \\
\hline$\%$ FFA (as Oleic acid) & 0.14 & 0.29 & 0.21 & 0.13 & 0.19 & 0.17 & 0.15 & 0.16 & 0.31 & 0.17 & 0.15 & 0.13 \\
\hline $\begin{array}{l}\text { Peroxide value (meq } \\
\mathrm{O}_{2} / \mathrm{kg} \text { oil) }\end{array}$ & 4.22 & 5.69 & 5.94 & 6.63 & 5.23 & 5.88 & 5.55 & 5.85 & 4.79 & 4.57 & 7.07 & 4.08 \\
\hline $\mathrm{K}_{232}$ & 0.621 & 0.817 & 0.906 & 0.584 & 0.601 & 1.004 & 0.521 & 0.613 & 0.397 & 0.661 & 0.775 & 0.891 \\
\hline$K_{270}$ & 0.028 & 0.028 & 0.013 & 0.009 & 0.007 & 0.001 & 0.030 & 0.024 & 0.011 & 0.018 & 0.030 & 0.007 \\
\hline$\Delta \mathrm{k}$ & 0.0005 & 0.001 & 0 & 0.0005 & 0 & 0 & 0 & 0 & 0.0005 & 0 & 0 & 0 \\
\hline
\end{tabular}

Data shown in table (5) demonstrated that the various quality parameters of virgin olive oils are in the range of IOC trade standard and classify as extra virgin olive oil (IOC, 2013b). Overall mean values of the oils from organically cultivated olive trees exhibited higher quality, e.g., lower acidity value, lower peroxide index, higher stability and higher organoleptic scoring (Gutierrez et al., 1999). 


\subsection{Total phenols content and oxidative stability:}

In the case of (Organic fertilization $+100 \%$ water irrigation required), all trees were irrigated to replace the crop water demand, so we assume water stress of our experimental trees were low. The observed differences between treatments on polyphenol content must be attributed to differences in organic fertilization.

Table (6) shows the effect of organic fertilization and $100 \%$ irrigation on Total phenols and oxidative stability of Maraqi virgin olive oil. VOO obtained from the T12 treatment showed the highest total phenols content $(327.45 \mathrm{mg} / \mathrm{kg})$ followed by VOOs obtained from the T10 and T8 treatments ( 275.10 and $263.62 \mathrm{mg} / \mathrm{kg}$ ). Also, VOO obtained from T7 had the lowest total phenols content $(214.36 \mathrm{mg} / \mathrm{kg})$.

Table 6. Effect of organic fertilization and irrigation on Total phenols and oxidative stability of cv. Maraqi virgin olive oil.

\begin{tabular}{|c|c|c|c|c|c|c|c|c|c|c|c|c|}
\hline & \multicolumn{10}{c|}{ Treatments } \\
\cline { 2 - 13 } $\begin{array}{c}\text { Characteris } \\
\text { tics }\end{array}$ & \multicolumn{8}{|c|}{ Organic fertilization $+75 \%$ irrigation } & \multicolumn{7}{c|}{ Organic fertilization $+100 \%$ irrigation } \\
\cline { 2 - 13 } & $\mathrm{T} 1$ & $\mathrm{~T} 2$ & $\mathrm{~T} 3$ & $\mathrm{~T} 4$ & $\mathrm{~T} 5$ & $\mathrm{~T} 6$ & $\mathrm{~T} 7$ & $\mathrm{~T} 8$ & $\mathrm{~T} 9$ & $\mathrm{~T} 10$ & $\mathrm{~T} 11$ & $\mathrm{~T} 12$ \\
\hline $\begin{array}{c}\text { Total } \\
\text { phenols } \\
\text { (mg/kg) }\end{array}$ & 254. & 295. & 280. & 327. & 243. & 339. & 214. & 263. & 215. & 275. & 231. & 327. \\
\hline $\begin{array}{c}\text { Oxidative } \\
\text { stability }\end{array}$ & 30.8 & 36.6 & 33.9 & 40.5 & 30.6 & 42.3 & 23.3 & 31.6 & 27.1 & 32.5 & 28.7 & 37.1 \\
(h) & 8 & 8 & 6 & 5 & 6 & 1 & 7 & 3 & 5 & 1 & 8 & 2 \\
\hline
\end{tabular}

Data in Table (6) revealed that VOOs obtained from the T10 (75\% compost + $100 \%$ water irrigation required), T8 ( $75 \%$ poultry $+100 \%$ water irrigation required) treatments higher in total phenols content ( 275.10 and $263.62 \mathrm{mg} / \mathrm{kg}$, respectively) than VOOs obtained from the T9(100\% compost $+100 \%$ water irrigation required), T7 $(100 \%$ poultry $+100 \%$ water irrigation required) treatments ( 215.34 and 214.36 $\mathrm{mg} / \mathrm{kg}$, respectively). This observed reduction may be related to $\mathrm{N}$ content in used organic fertilizers where $\mathrm{N}$ content in T9 (100\% Compost) and $\mathrm{T} 7(100 \%$ Poultry manure) were higher than T10 (75\% Compost) and T8 (75\% Poultry manure). These results agreed with Fernandez-Escobar et al.(2006).

In fact, reduced nitrogen applications are typically associated with an increase of phenolic compounds. In a recent study conducted in two adult 'Picual' olive orchards, a decrease in oil polyphenol content was found with increased nitrogen dose applied either to soil or soil and foliage, depending on the orchard. In this case, leaf 
nitrogen levels were always above the threshold limit for deficiency and it showed a linear increase with the amount of fertilizer applied (Fernandez-Escobar et al., 2006).

Data also, Table (6), showed that VOO obtained from T6 (Farm Yard manure, FYM) had the highest total phenols content $(339.84 \mathrm{mg} / \mathrm{kg})$ as compared with T4 (compost) $(327.35 \mathrm{mg} / \mathrm{kg}$ ) may be related to higher content of organic matter in FYM (46.65\%) than compost (31.03\%) (Table: 3 ). Organic matter is not only necessary for plant nutrition as slow release fertilizers but also essential for efficient plant production system (AL-Kahtani and Ahmed, 2012).

On other side, In the case of (Organic fertilization $+100 \%$ water irrigation required), VOO obtained from the T12 treatment showed the highest resistance to oxidation, as a result of the highest values observed $(37.21 \mathrm{~h})$ of oxidative stability (Table 6). This parameter was reduced by $12.42 \%, 14.79 \%$ and $37.04 \%$ in T10, T8 and $T 7$, respectively. This decrease in oxidative stability is usually explained by the decrease in total phenols content. Given this assumption, several researchers have demonstrated that polyphenols contents are, among the minor compounds, the group more correlated with oxidative stability (Fernandes-Silva et al., 2013). It has been recognized that polyphenols and tocopherols are substances with natural antioxidant properties and their presence in olive oils has been associated to their general quality, improving stability, nutritional value and sensorial properties (Boskou et al., 2006).

Effect of irrigation on total phenols and oxidative stability of VOOs (Table: 6) showed that VOOs obtained from $75 \%$ water irrigation required had higher total phenol content and higher oxidative stability than those treatment with $100 \%$ water irrigation required. This was may be to stress of the lack of water. It is known that high polyphenol content could occur in stressed olive trees, probably because of the activation of enzymes such as phenylalanine ammonia lyase, which catalyzes the synthesis of most of the phenolic compounds. The lack of water, for instance, has a marked effect on the accumulation of polyphenols in olive oil (Morales-Sillero et al., 2007).

In this study $100 \%$ irrigation reqiured treatments (from T7 to T12) revealed a tendency to decrease the concentrations of total polyphenols, which may range from 214.36 to 327.45 (Table 6), which corroborate with observations in other cultivars cited by Fernandes-Silva et al.(2013).

The differences in oil polyphenol content between T12 $(327.45 \mathrm{mg} / \mathrm{kg})$ and T6 (339.84 mg/kg) treatments (Table.6) could be also explained, in part, by the increase in fresh fruit weight (Table.4) subsequently, increase in fruit water content, which could affect the extraction of partially soluble phenolic compounds as observed in a previous study cited by Morales-Sillero et al.(2007). 
A good relationship was observed between total polyphenols and water stress (Table 6), which is in accordance with previous reports cited by Fernandes-Silva et al.(2013). Therefore, olive trees that had been exposed to a certain level of water deficit produced oils with higher concentrations of polyphenols, which were seemingly richer in the olive fruit. In addition, previous studies in cv. Cornicabra indicated that the effect of water status of olive trees throughout the year affects the concentration of phenolics and not just during the oil accumulation. These authors found that the total phenol content of the rain fed trees was sharply reduced in years which had a rainy spring (the last rain falling in June) and a dry autumn (Fernandes-Silva et al., 2013).

\subsection{Chlorophylls and Carotenoids:}

Virgin olive oil color is the result of green and yellow hues due to the presence of chlorophylls and carotenoids. It is influenced by olive cultivar, maturation index, production zone, extraction system, and storage conditions. Therefore it is considered as a quality index though no standardized method exists for its measurement. The presence of carotenoids in olive oil is closely related to that of green pigments (Boskou, 2006)

Table (7) shows chlorophyll, and carotene content of cv. Maraqi virgin olive oil. VOO obtained from T12 had the highest content of Chlorophyll $b$, and Total Chlorophyll. While, VOO obtained from T9 had the highest content of Carotene.

Effect of irrigation on Chlorophyll $a$ of VOOs (Table:7) showed that VOOs obtained from $75 \%$ water irrigation required had higher Chlorophyll $a$ than those treatments with $100 \%$ water irrigation required, except for T5 and T11. Also, VOOs obtained from $75 \%$ irrigation, had higher Carotene than VOOs obtained from $100 \%$ irrigation, except for T1 and T3.

Carotenoids, especially $\beta$-carotene are efficient VOO protectors against photooxidation, since they are capable of deactivating the oxygen singlet giving back its triplet status (Bendini et al., 2010). For that, VOOs obtained from (Organic fertilization $+75 \%$ irrigation) had higher oxidative stability than those from (Organic fertilization $+100 \%$ irrigation).

Chlorophylls demonstrate both antioxidant and prooxidant activity depending on the oil system and storage conditions. The capacity of the chlorophyll molecule to absorb light energy and transfer it to chemical substances makes it very active in lipid photo-oxidation in VOO. Chlorophylls may also act as low antioxidants during oxidation in the dark - absence of light - probably due to its capacity to donate hydrogen (Bendini et al., 2010). 
Table 7. Effect of organic fertilization and irrigation on Chlorophyll and Carotene of cv. Maraqi virgin olive oil.

\begin{tabular}{|c|c|c|c|c|c|c|c|c|c|c|c|c|}
\hline \multirow{3}{*}{ Characteristics } & \multicolumn{12}{|c|}{ Treatments } \\
\hline & \multicolumn{6}{|c|}{ Organic fertilization $+75 \%$ irrigation } & \multicolumn{6}{|c|}{ Organic fertilization $+100 \%$ irrigation } \\
\hline & T1 & $\mathrm{T} 2$ & T3 & T4 & T5 & T6 & $\mathrm{T7}$ & T8 & T9 & $\mathrm{T} 10$ & $\mathrm{~T} 11$ & T12 \\
\hline Chlorophyll a & 0.482 & 0.541 & 0.216 & 0.500 & 0.224 & 0.886 & 0.338 & 0.539 & 0.184 & 0.352 & 0.886 & 0.796 \\
\hline Chlorophyll $b$ & 0.679 & 0.334 & 0.236 & 0.439 & 0.253 & 0.784 & 0.347 & 0.759 & 0.335 & 0.531 & 0.403 & 0.911 \\
\hline Total Chlorophyll & 1.285 & 1.022 & 0.507 & 1.071 & 0.535 & 1.904 & 0.772 & 1.434 & 0.564 & 0.970 & 1.532 & 1.913 \\
\hline Carotene & 0.167 & 0.381 & 0.127 & 0.580 & 0.384 & 0.562 & 0.347 & 0.216 & 0.607 & 0.271 & 0.151 & 0.378 \\
\hline
\end{tabular}




\subsection{Fatty acid composition:}

Results revealed that fatty acid composition was also modified by the organic fertilization treatments (Table: 8 ) and all fatty acid composition were in the range of International olive council (IOC) (IOC, 2013b). In the case of (Organic fertilization $+75 \%$ irrigation), monounsaturated fatty acids increased as the fertilizer dose increased. On the contrary, the content of polyunsaturated fatty acids increased with decreasing of the fertilizer dose. In particular, the oleic acid content increased and linoleic fatty acid content decreased with fertilizer dose increased. The monounsaturated/polyunsaturated fatty acid ratio increased as the fertilizer dose increased.

Table 8. Effect of organic fertilization and irrigation on fatty acid composition of cv.

Maraqi virgin olive oil.

\begin{tabular}{|c|c|c|c|c|c|c|c|c|c|c|c|c|}
\hline \multirow{3}{*}{ Fatty acid } & \multicolumn{12}{|c|}{ Treatments } \\
\hline & \multicolumn{6}{|c|}{ Organic fertilization $+75 \%$ irrigation } & \multicolumn{6}{|c|}{ Organic fertilization $+100 \%$ irrigation } \\
\hline & $\mathrm{T} 1$ & $\mathrm{~T} 2$ & T3 & $\mathrm{T} 4$ & T5 & T6 & $\mathrm{T7}$ & T8 & T9 & $\mathrm{T} 10$ & $\mathrm{~T} 11$ & T12 \\
\hline $\mathrm{C}_{16: 0}$ & 10.56 & 10.83 & 10.20 & 11.32 & 10.39 & 10.35 & 10.75 & 10.69 & 10.97 & 10.27 & 10.70 & 10.30 \\
\hline $\mathrm{C}_{16: 1}$ & 0.33 & 0.38 & 0.32 & 0.38 & 0.32 & 0.33 & 0.39 & 0.34 & 0.35 & 0.37 & 0.34 & 0.31 \\
\hline$C_{17: 0}$ & 0.05 & 0.04 & 0.05 & 0.05 & 0.05 & 0.05 & 0.05 & 0.05 & 0.06 & 0.05 & 0.05 & 0.05 \\
\hline$C_{17: 1}$ & 0.05 & 0.05 & 0.05 & 0.05 & 0.06 & 0.06 & 0.06 & 0.05 & 0.07 & 0.05 & 0.05 & 0.05 \\
\hline$C_{18: 0}$ & 2.89 & 2.67 & 2.88 & 3.03 & 2.75 & 2.83 & 2.59 & 2.88 & 2.67 & 2.68 & 2.80 & 3.19 \\
\hline $\mathrm{C}_{18: 1}$ & 79.42 & 79.27 & 78.89 & 77.54 & 79.70 & 79.53 & 77.91 & 78.67 & 77.60 & 79.11 & 78.16 & 78.20 \\
\hline $\mathrm{C}_{18: 2}$ & 5.23 & 5.25 & 6.11 & 6.19 & 5.39 & 5.38 & 6.52 & 5.86 & 6.88 & 5.98 & 6.55 & 6.47 \\
\hline $\mathrm{C}_{18: 3}$ & 0.59 & 0.63 & 0.59 & 0.59 & 0.52 & 0.57 & 0.65 & 0.57 & 0.56 & 0.60 & 0.54 & 0.56 \\
\hline $\mathrm{C}_{20: 0}$ & 0.41 & 0.42 & 0.42 & 0.45 & 0.40 & 0.41 & 0.58 & 0.41 & 0.39 & 0.40 & 0.38 & 0.42 \\
\hline$C_{20: 1}$ & 0.33 & 0.33 & 0.36 & 0.31 & 0.35 & 0.35 & 0.37 & 0.34 & 0.34 & 0.36 & 0.35 & 0.35 \\
\hline $\mathrm{C}_{22: 0}$ & 0.09 & 0.09 & 0.08 & 0.09 & 0.07 & 0.09 & 0.08 & 0.09 & 0.11 & 0.08 & 0.08 & 0.10 \\
\hline$C_{24: 0}$ & 0.05 & 0.04 & 0.05 & 0.00 & 0.00 & 0.05 & 0.05 & 0.05 & 0.00 & 0.05 & 0.00 & 0.00 \\
\hline$\Sigma$ SFA* & 14.05 & 14.09 & 13.68 & 14.94 & 13.66 & 13.78 & 14.10 & 14.17 & 14.20 & 13.53 & 14.01 & 14.06 \\
\hline$\Sigma$ USFA** & 85.95 & 85.91 & 86.32 & 85.06 & 86.34 & 86.22 & 85.90 & 85.83 & 85.80 & 86.47 & 85.99 & 85.94 \\
\hline MUSFA & 80.13 & 80.03 & 79.62 & 78.28 & 80.43 & 80.27 & 78.73 & 79.40 & 78.36 & 79.89 & 78.90 & 78.91 \\
\hline PUSFA & 5.82 & 5.88 & 6.70 & 6.78 & 5.91 & 5.95 & 7.17 & 6.43 & 7.44 & 6.58 & 7.09 & 7.03 \\
\hline $\mathrm{C}_{18: 1 / \mathrm{c} 18: 2}$ & 15.18 & 15.10 & 12.91 & 12.53 & 14.79 & 14.78 & 11.95 & 13.42 & 11.28 & 13.23 & 11.93 & 12.09 \\
\hline USFA/SFA & 6.12 & 6.10 & 6.31 & 5.69 & 6.32 & 6.26 & 6.09 & 6.06 & 6.04 & 6.39 & 6.14 & 6.11 \\
\hline $\begin{array}{l}\text { MUSFA / } \\
\text { PUSFA }\end{array}$ & 13.77 & 13.61 & 11.88 & 11.55 & 13.61 & 13.49 & 10.98 & 12.35 & 10.53 & 12.14 & 11.13 & 11.22 \\
\hline
\end{tabular}

* SFA : Saturated Fatty Acids.

** USFA : Unsaturated Fatty Acids. 
These results are interesting for olive oil because the beneficial effects on human health are attributed, in part, to the high content of monounsaturated fatty acids, particularly oleic acid. In addition, a greater oleic acid content but a lower linoleic acid content seems to improve oil oxidative stability. A significant decrease in saturated fatty acids content and so an increase in unsaturated/saturated and polyunsaturated/saturated fatty acid ratios when supplied to the soil around the tree trunks high levels of $\mathrm{N}$ and $\mathrm{K}$ in a 'Carrasquena' olive orchard (Morales-Sillero et al., 2007).

Palmitic and Linoleic acids of VOOs obtained from 75\%water irrigation required treatments were decreased with fertilizer dose increased.

In the case of (Organic fertilization $+100 \%$ irrigation), the highest Stearic, Oleic acids contents were obtained from lower nitrogen dose (T8 and T10) and the lowest content was obtained from the higher nitrogen dose (T7 and T9). The highest linoleic acid content was obtained from the higher nitrogen dose (T7 and T9) and the lowest linoleic acid content was obtained from lower nitrogen dose (T8 and T10).

Data in Table (8) showed that effect of irrigation on Fatty acid composition of cv. Maraqi virgin olive oil. Oleic acid, the most abundant fatty acid in all samples of olive oil (77.54-79.70\%), showed a slight increase in concentration of oleic acid for VOOs obtained from $75 \%$ water irrigation required treatments as compared to those $100 \%$ water irrigation required treatments, except for T4 and T10.

Also, results revealed that a slight decrease in concentration of Linoleic acid of VOOs obtained from $75 \%$ water irrigation required treatments as compared to those $100 \%$ water irrigation required treatments, except for T4 and T10.

Changes in the ratio of unsaturated/saturated fatty acids affect organoleptic properties of olive oil, as oil with a high content of saturated fatty acids is more viscous and remains longer in contact with mucous membranes of the oral cavity, giving rise to the "fatty" defect (Fernandes-Silva et al., 2013).

Also, the monounsaturated/polyunsaturated acid ratio influenced by irrigation, this ratio higher in VOOs obtained from $75 \%$ water irrigation required treatments than those obtained from $100 \%$ water irrigation required treatments, except for T4 and T10.

Indeed, studies on the contribution of different compounds in virgin olive oil stability reported that the oleic/linoleic acid ratio was one of the main determinants of oxidative stability. It is well-known that polyunsaturated fatty acids are more susceptible to oxidation, and consequently, could shorten the shelf life of the oil. Furthermore, olive oil oxidative stability might depend on some synergistic effects (still 
unknown) among fatty acid composition, phenolic compounds, tocopherols, carotenoids and chlorophylls (Fernandes-Silva et al., 2013).

The monounsaturated/polyunsaturated fatty acid, oleic/linoleic fatty acid ratios, (Table: 8 ), were higher in VOOs obtained from $75 \%$ water irrigation required treatments than those obtained from trees irrigated with $100 \%$ water irrigation required treatments, except for $\mathrm{T} 4$ and $\mathrm{T} 10$. These results have a positive relation with phenolic content and oxidative stability.

Furthermore, the polyphenol content and oleic/linoleic fatty acid ratio as well as the monounsaturated/polyunsaturated fatty acid ratio (Tables 6 and 8) probably influenced the oil oxidative stability.

High positive correlations between oil oxidative stability and polyphenol content had been observed by other authors and also found a positive correlation between oil oxidative stability and the oleic/linoleic fatty acid ratio (Morales-Sillero et al., 2007).

\subsection{Sensory analysis and overall quality index:}

Table (9) shows the effect of organic fertilization and irrigation on sensory analysis and overall quality index of cv. Maraqi virgin olive oil. Results revealed that no defects in any of the studied oils and they are classified as extra virgin olive oils. Data from sensory analysis of Oils from the $100 \%$ water irrigation required treatments were less fruity, less bitter and less pungent than those of the $75 \%$ water irrigation required treatments.

Table 9. Effect of organic fertilization and irrigation on sensory analysis and overall quality index of cv. Maraqi virgin olive oil.

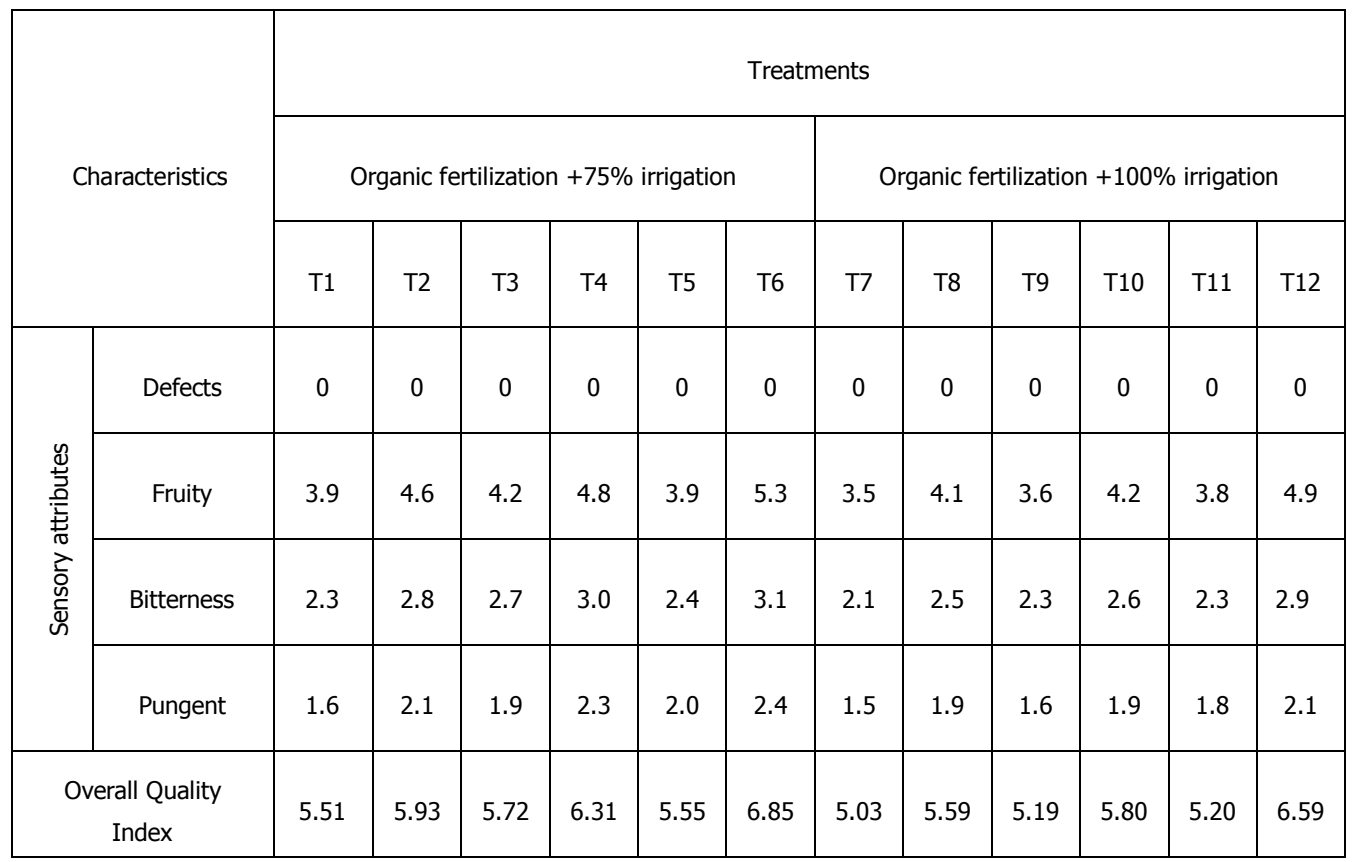


Results revealed that VOOs obtained from T6 and T12 had the highest score of fruity, bitterness and pungent attributes (Table: 9), on the other hand VOO obtained from T7 had the lowest score. These results related to phenolic content in VOOs (Table: 6), VOOs from T6 and T12 had the highest content and VOO from T7 had the lowest content of phenolic compounds.

Phenolic substances do not only affect virgin olive oil stability, they also contribute to oil flavour and aroma, especially to the typical bitter taste of olive oil, which is a positive attribute in the sensory evaluation of virgin olive oils and a typical organoleptic characteristic of the Cornicabra variety (Salvador et al., 2003).

Therefore, $75 \%$ water irrigation required treatments enhances the organoleptic values of the oil of Maraqi cultivar, particularly appreciated for the more of fruity, bitter and pungent attributes than those $100 \%$ water irrigation required treatments.

Data also, in Table (9), showed that VOOs from T6 and T12 had the highest score of Overall Quality Index and VOO from T7 had the lowest score. This is related to low acidity, low peroxide value, $\mathrm{k}_{270}$ and high score of sensory analysis.

Overall mean values of the oils from organically cultivated olive trees exhibited higher quality, e.g., lower acidity value, lower peroxide index, higher stability and higher organoleptic scoring (Gutiérrez et al., 1999).

\section{CONCLUSION}

In conclusion, results of this study indicated that all organic c.v Maraqi VOOs were classified as extra virgin olive oil. VOOs obtained from Farm yard manure and compost had the highest phenols and oxidative stability. $\mathrm{N}$ content in used organic fertilizers had reverse (negative) relationship on content of phenols. On the contrary, Organic matter had positive relationship on content of phenols.

VOOs obtained from $75 \%$ irrigation had higher total phenol content and higher oxidative stability than those treatment with $100 \%$ irrigation.

In the case of (Organic fertilization $+75 \%$ irrigation), monounsaturated fatty acids increased as the fertilizer dose increased. On the contrary, the content of polyunsaturated fatty acids decreased with it. In particular, the oleic acid content increased and linoleic fatty acid content decreased with fertilizer dose increased. The monounsaturated/polyunsaturated fatty acid ratio increased as the fertilizer dose increased. 


\section{REFERENCES}

1. AL-Kahtani, S.H and M.A. Ahmed. 2012. Effect of Different Mixtures of Organic Fertilizers on Vegetative Growth, Flowering, Fruiting and Leaf Mineral Content of Picual Olive Trees. American-Eurasian J. Agric. \& Environ. Sci., 12 (8): 1105-1112.

2. Bendini, A., L. Cerretani, M.D. Salvador, G. Fregapane, G. Lercker. 2010. Stability of the Sensory Quality of Virgin Olive Oil during Storage. An Overview

3. Boskou D, M. Tsimidou, G. Blekas. 2006. Polar Phenolic Compounds: In D. Boskou (Ed.). Oil Chemistry and Technology, Champaign: AOCS Press, pp.4167.

4. Cossignani, L., M.S. Simonetti and P. Damiani. 2005. Biocatalyzed acidolysis of olive oil triacylglycerols with $9 c, 11 t$ and $10 t, 12 c$ isomers of conjugated linoleic acid Eur. Food Res. Technol., 220, 267-271.

5. EEC., 1991. Official Journal European Communities (1991) n.L. 248 of September 5, Regulation CE no 2568/91.

6. Fernandes-Silva, A.A., Gouveia, J.B., Vasconcelos, P., Ferreira, T.C. and Villalobos, F.J. 2013. Effect of different irrigation regimes on the quality attributes of monovarietal virgin olive oil from cv. "Cobrançosa". grasas y aceites, 64 (1), enero-marzo, 41-49.

7. Fernandez-Escobar, R., G. Beltran, M.A. Sanchez- Zamora, J. Garcia-Novelo, M.P. Aguilera, and M. Uceda. 2006. Olive oil quality decreases with nitrogen over-fertilization. HortScience 41:215-219.

8. Gamez-Meza, N., T. A. Nriega-Rodiguez, L. A. Medira-Jularz, J., OrtegaGracia, R. Cazarazez-Casanova and O. Angulo-Guerrero. 1999. Antioxidant activity in soybean oil of extracts from Thompson grape bagasse. JAOCS, 76, 1445-1447.

9. Gutierrez, R. F. 1989. Determinacion de la estabilidad oxidativa de a- ceites de oliva virgenes : Comparacidn entre el mètodo del oxigen. active (AOM) y el mètodo Rancimate. Grasas y Aceites, 40, 1 - 5.

10. Gutierrez F., T. Arnaud, M.A. Albi (1999). Influence of ecological, cultivation on virgin olive oil quality. J. Am. Oil Chem. Soc. 76:617-621.

11. IOC. 1990. International olive oil council, Activities of cooperation technique. Olivae, 38, 12.

12. IOC. 2013a. Sensory analysis of olive oil. Method for the organoleptic assessment of virgin olive oil. COI/T.20/Doc. No 15/Rev. 6, November 2013. 
13. IOC. 2013b. Trade standard applying to olive oils and olive-pomace oils.

COI/T.15/NC No 3/Rev. 7.May 2013.

14. Morales-Sillero, A., J.E. Fernandez, G. Beltran, R. Jimenez and A.Troncoso, 2007. Influence of fertigation in 'Manzanilla de Sevilla' olive oil quality. HortScience 42:1157-1162.

15. Morales-Sillero, A., R. Jimenez, J.E., Fernandez, A. Troncoso, and L. Rejano. 2008. Effect of Fertigation on the 'Manzanilla de Sevilla' Table Olive Quality Before and After "Spanish-style" Green Processing. HORTSCIENCE 43(1):153158.

16. Motavalli, P.P., R.P. Singh, M.M. Anders. 1994. Perception and Management of Farmyard Manure in the Semiarid Tropics of India. Agr. Syst., 46 (2), 189204.

17. Salvador, M. D., F. Aranda, S. Gomez-Alonso and G. Fregapane. 2003. Influence of extraction system, production year and area on Cornicabra virgin olive oil: a study of five crop seasons Food Chemistry, 80 , 359-366.

18. Wensttein. D.U. 1957. Chlorophyll let ale and Der Supuni Kros Kapisene Jor Winneck Sec. Der. Plastiden. Experimental Cell. Research 12: 427. 


\section{تأثير التسميد العضوى والرى لصنف الزيتون المراقى على جودة زيت الزيتون البكر}

\section{محمد السيد إسماعيل الصردى' - عمرو صلاح محمد.r - انعام شعبان أحمد محمد'}

ا - مركز الجحوث الزراعية - معهل بحوث تكنولوجيا الأغذية - قسم بحوث الزيوت والدهون - الجيزة - مصر.

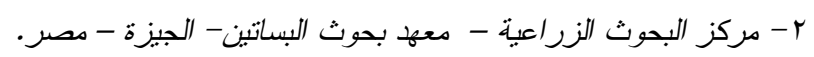

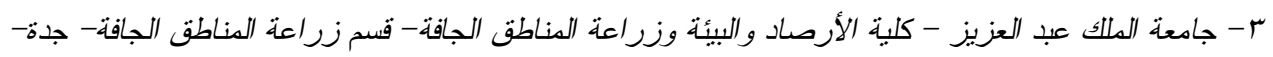
السعودية.

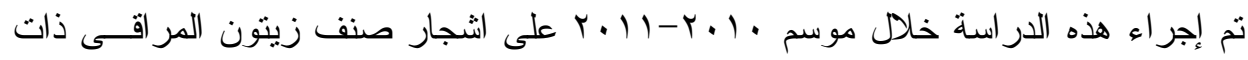
عمر V سنوات بمزرعة عضوية ببرقاش بمحافظة الجيزة و تهدف الدر اسة لمعرفة تـأثير النســـيد العضوى و الرى لصنف الزيتون المر اقى على جودة زيت الزيتون و كانت المعاملات كالتالى : 1-

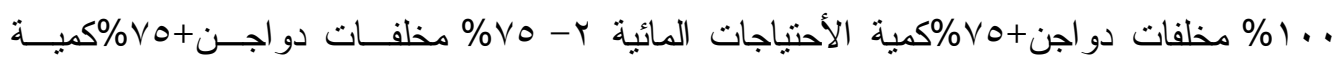

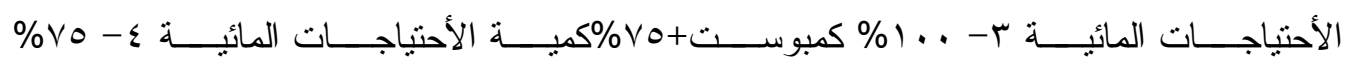

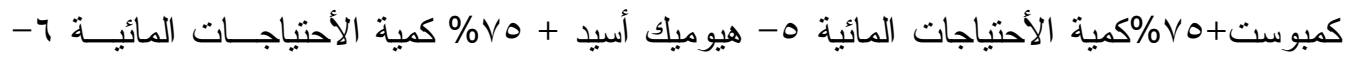

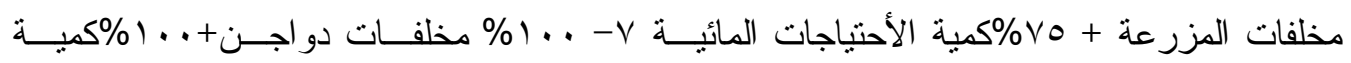

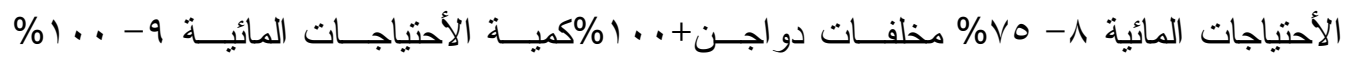

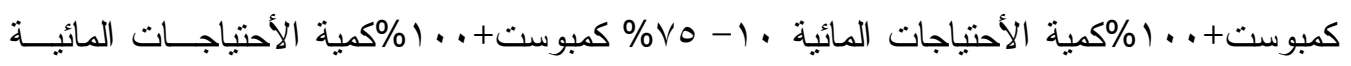


الأحتياجات المائية.

أوضحت نتائج هذه الدر اسة أن جميع زيوت الزيتون العضوبة كانت زيـــوت بكــر ممتـــاز





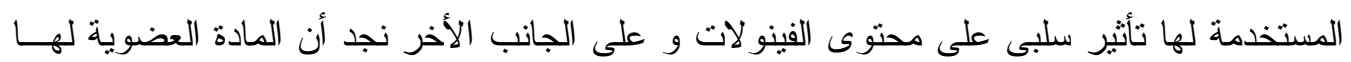
تأثنير ايجابى على محتوى الفينو لات.





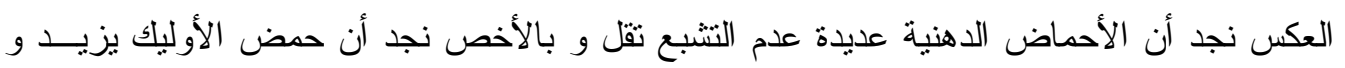

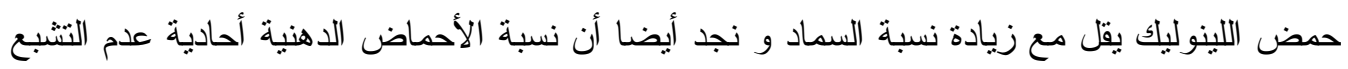
إلى الأحماض الدهنيةعديدة عدم التشبع نزيد مع زيادة نسبة السماد.



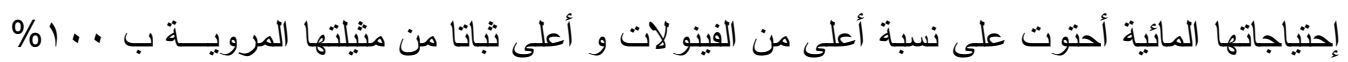

